\title{
HIGH-IMPACT DROP EXERCISE ALTERS MECHANICAL PROPERTIES IN OSTEOPENIC BONE
}

\author{
EXERCICIO DE QUEDA ALTERA AS PROPRIEDADES MECÂNICAS EM OSSO OSTEOPÊNICO \\ EL EJERCICIO DE CAÍDA ALTERA LAS PROPIEDADES MECÁNICAS EN HUESO OSTEOPÉNICO
}

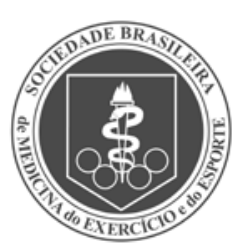

Original Article

Artigo Original

Artículo Original
Fábio Senishi Asano ${ }^{1}$

(Fisioterapeuta)

Fernando Fonseca de Almeida e Val ${ }^{2}$ (Fisioterapeuta)

Thiago Teixeira Serafim ${ }^{3}$

(Graduando do Curso de Fisioterapia)

Maurício José Falcai ${ }^{1}$

(Fisioterapeuta)

Rodrigo Okubo ${ }^{3}$ (Fisioterapeuta)

Antônio Carlos Shimano²

(Engenheiro Mecânico)

1. Universidade de São Paulo,

Faculdade de Medicina de

Ribeirão Preto, Departamento

de Biomecânica, Medicina

e Reabilitação do Aparelho

Locomotor, Ribeirão Preto, SP, Brazil.

2. Escola Superior de Ciências da

Saúde, Universidade do Estado do

Amazonas, Manaus, AM, Brazil.

3. Universidade do Estado de

Santa Catarina, Departamento de

Fisioterapia, Florianópolis, SC, Brazil.

\section{Correspondence:}

Rodrigo Okubo

Departamento de Fisioterapia, Universidade do Estado de Santa Catarina, Brazil. Rua Pascoal Simone, 358, Florianopolis, SC, Brazil. 88080-350.

rodrigo.okubo@udesc.br rokubo@ymail.com

\begin{abstract}
Introduction: Osteopenia is a reversible condition and precedes osteoporosis. Physical activity and mechanical loading appear to play an important role in the regulation of bone homeostasis, without the side effects of targeted drug therapy. However, there is controversy as to which type of stimulus promotes more effective adaptations with respect to mechanical properties of bones. Objective: To investigate the effects of high-impact drop training on bone structure after ovariectomy-induced osteopenia in 40 10-week-old female Wistar rats. Methods: Twenty female rats (prevention program) were randomly assigned into two groups $(n=10)$ : Ovariectomized sedentary $\left(\mathrm{OVX} \mathrm{X}_{\mathrm{s}}\right.$ ), and $\mathrm{OVX}$ trained $\left(\mathrm{OVX}+\mathrm{Drop}_{\mathrm{t}}\right) . \mathrm{OVX}+\mathrm{Drop}_{\mathrm{t}}$ animals began training 3 days after surgery. Another twenty female rats (treatment program) were randomly assigned to two other groups $(n=10)$ : Ovariectomized sedentary $\left(O V X_{s}\right)$, and $O V X$ trained $\left(\mathrm{OVX}+\right.$ Drop $\left._{\mathrm{t}}\right) . \mathrm{OVX}+$ Drop $_{\mathrm{t}}$ animals began training 60 days after surgery. The rats in the trained groups were dropped from $40 \mathrm{~cm}$ height 20 times/day, 5 days/week over a period of 12 weeks period. At the end, the biomechanical tests were analyzed. Results: The final load and stiffness of the left tibia in the trained groups were higher than in the sedentary groups $(p<0.05)$. Conclusions: Dropping exercise induced favorable changes in bone mechanical properties. Highimpact drop exercise is effective to prevent bone loss after ovariectomy even when osteopenia is already established.
\end{abstract}

Keywords: bone diseases, metabolic; ovariectomy; exercise therapy.

\section{RESUMO}

Introdução: A osteopenia é uma doença reversivel e precede a osteoporose. A atividade física e a carga mecânica parecem desempenhar um papel importante na regulação da homeostase óssea, sem os efeitos colaterais da terapia medicamentosa direcionada. No entanto, é controverso qual tipo de estímulo promove adaptações mais eficazes com relação às propriedades mecânicas dos ossos. Objetivo: Investigar os efeitos do treinamento de queda com impacto sobre a estrutura óssea depois de osteopenia induzida por ovariectomia em 40 ratas Wistar com 10 semanas de idade. Métodos: Vinte ratas (programa de prevenção) foram distribuídas aleatoriamente em dois grupos ( $n=10)$ : Ovariectomizadas sedentárias $\left(\mathrm{OV} X_{s}\right)$ e OVX treinadas (OVX + Drop $)_{t}$. Os animais OVX + Drop ${ }_{t}$ começaram a treinar três dias após a cirurgia. Outras vinte ratas (programa de tratamento) foram alocadas aleatoriamente em outros dois grupos $(n=10)$ : Ovariectomizadas sedentários (OVX) e OVX exercitadas (OVX + Dropt). Os animais OVX + Dropt iniciaram o treinamento 60 dias após a cirurgia. As ratas nos grupos treinados foram deixadas cair 20 vezes/dia, 5 dias/semana, de altura de 40 $\mathrm{cm}$ durante um período de 12 semanas. Ao final, foram analisados os testes biomecânicos. Resultados: A carga finale a rigidez da tíbia esquerda nos grupos treinados foram maiores do que nos grupos sedentários $(p<0,05)$. Conclusões: O exercício de queda provocou alterações favoráveis nas propriedades mecânicas dos ossos. O exercício de queda com impacto é eficaz para prevenir a perda óssea após ovariectomia, mesmo quando a osteopeniajá está estabelecida.

Descritores: doenças ósseas metabólicas; ovariectomia; terapia por exercício.

\section{RESUMEN}

Introducción: La osteopenia es una enfermedad reversible y precede a la osteoporosis. La actividad física y la carga mecánica parecen desempeñar un papel importanteen la regulación de la homeostasis ósea, sin los efectos secundarios de la terapia farmacológica dirigida. Sin embargo, es controvertido qué tipo de estímulo promueve adaptaciones más eficaces con respecto a las propiedades mecánicas de los huesos. Objetivo: Investigar los efectos del entrenamiento de caída con alto impacto sobre la estructura ósea después de osteopenia inducida por ovariectomía en 40 ratas Wistar hembras de diez semanas de edad. Métodos: Se asignaron aleatoriamente veinte ratas (programa de prevención) en dos grupos $(n=10)$ :

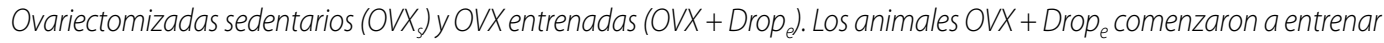
tres días después de la cirugía. Otras veinte ratas hembras (programa de tratamiento) fueron asignadas aleatoriamente a otros dos grupos $(n=10)$ : Ovariectomizadas sedentarias (OVX) y OVX entrenadas (OVX + Drope). Los animales OVX + Drope iniciaron el entrenamiento 60 días después de la cirugía. Las ratas en los grupos entrenados se dejaron caer de una altura de $40 \mathrm{~cm} 20$ veces/día, 5 días/semana durante un período de 12 semanas. Al final, se analizaron las pruebas biomecánicas. Resultados: La carga y rigidez de la tibia izquierda en los grupos entrenados fueron mayores queen los grupos sedentarios $(p<$ 0,05). Conclusiones: El ejercicio de caída provocó cambios favorables en las propiedades de los huesos. El ejercicio de caída con impacto es eficaz para prevenir la pérdida ósea después de la ovariectomía, incluso cuando la osteopenia ya está establecida.

Descriptores: enfermedades óseas metabólicas; ovariectomía; terapia por ejercicio. 


\section{INTRODUCTION}

Osteopenia is a reversible condition and precedes osteoporosis, being characterized by low bone mass and microstructural deterioration of bone tissue, leading to bone fragility and increased susceptibility to fractures ${ }^{1}$. According to the International Osteoporosis Foundation?2, about 200 million women worldwide suffer from osteoporosis. Physical activity and mechanical loading seems to play an important role in the regulation of bone homeostasis, without the side effects of targeted drug therapy ${ }^{3}$. Guadalupe-Grau, Fuentes, Guerra, \& Calbet (2009) ${ }^{4}$ reported that exercise increases peak of bone mass. However, non-weight bearing activities such as swimming and cycling exert little influence on bone mineral density (BMD) $)^{5}$ and are thus not suitable for prevention and treatment of osteoporosis.

High impact exercise is the most effective physical activity in eliciting an osteogenic response, as it causes transient high tension and deformation in bones 6 . Jumping appears to promote superior bone formation compared with low impact aerobic exercises ${ }^{7-12}$. The mechanical stress caused by high impact exercise is crucial for the structural and functional integrity of the skeletal system, since it increases BMD and other properties of bones ${ }^{6}$. However, it is controversial which type of stimulus promotes more effective adaptations regarding in bone mechanical properties.

The present study investigated whether drop exercise (eccentric stimuli), before and after ovariectomy-induced osteopenia, has beneficial effects on bone mechanical proprieties of rats in the mentioned conditions. Our hypothesis was that the chosen impact exercise regimen (prevention or treatment) would lead to increased levels of bone turnover, favoring bone resistance in both situations. We believe that the impact force is greater in this type of exercise when compared to other modalities, e.g. jumping.

\section{MATERIALS AND METHODS}

Female rats were used to evaluate the effects on bone in a prevention (before installed osteopenia) and a treatment (after installed osteopenia) program of high impact exercise.

The protocols for animal experimentation were previously approved by the Institutional Animal Care and Use Committee of the university (protocol number CETEA 182/2008).

Forty female Wistar rats, aged 10 weeks, were obtained from the University of São Paulo (Ribeirão Preto, SP, Brazil). The rats were housed in standard cages under constant temperature $\left(25^{\circ} \mathrm{C}\right)$ and a 12 -hour light-dark cycle. Food and water were provided ad libitum.
We use a system of sealed envelopes to allocate the mice within groups. An official of the central animal facility separated 40 animals all of the same age. We used a random numbers table to allocate blocks of ten rats. Starting with an arbitrary point in the table, we selected 4 sequential random numbers. The first number was assigned to the single row block, and the next was assigned to the double row block. These assignments were then arranged in an ascending order. This procedure produced a random sequence of consecutive surgery and treatment allocations. Sealed, opaque numbered envelopes containing no exercise or exercise assignments were prepared, with care being taken to make sure that the order of the envelopes exactly matched the allocation schedule.

The first 2 numbers were allocated to the prevention program, and the last 2 to the treatment program. On the day of surgery, an experienced veterinary surgeon, who performed all the operations, opened the sealed envelope allocation each numbered rat to have ovariectomy (OVX rats) procedure on OVX or OVX+Drop groups with each rat under anesthesia with intramuscular ketamine/xylazine $\left(30 \mathrm{mg} \mathrm{kg}^{-1} \mathrm{ketamine}\right.$ and $3 \mathrm{mg} \mathrm{kg}^{-1}$ xylazine, i.m.).

The ovariectomized rat bone loss model is suitable to study problems relevant to postmenopausal bone loss ${ }^{13}$. Ovariectomy was confirmed with follicle-stimulating hormone (FSH) dosage.

All analyses were performed by a researcher who did not know to which groups the animals belonged.

Rats in the training groups were dropped 20 times/day, 5 days per week, for 12 weeks. Each exercised rat was dropped of $40 \mathrm{~cm}$ in height with their hindlimbs. Rats were dropped at 3 second intervals, and 2-3 min were required to complete a training session.

\section{Experiment 1 - Prevention program}

Twenty rats were first randomly allocated to the prevention program, and then randomly allocated to one the following two groups: Ovariectomized $(\mathrm{OVX})$ sedentary $\left(\mathrm{OVX} \mathrm{P}_{\mathrm{p}} n=10\right)$, and OVX exercised $\left(\mathrm{OVX}+\operatorname{Drop}_{\mathrm{p}} ; n=10\right)$

OVX+Drop rats in the prevention protocols began their training 3 days after surgery, for 12 weeks. The hypothesis of this experiment is that high-impact exercise can prevent bone become osteopenic (Figure 1).

\section{Experiment 2 - Treatment program}

In the treatment protocols, the rats began their training 60 days after surgery, for 12 weeks ( 8 weeks +12 weeks $=20$ week). We hypothesized that high-impact exercise can arrest and/or reverse the osteopenia caused by ovariectomy.

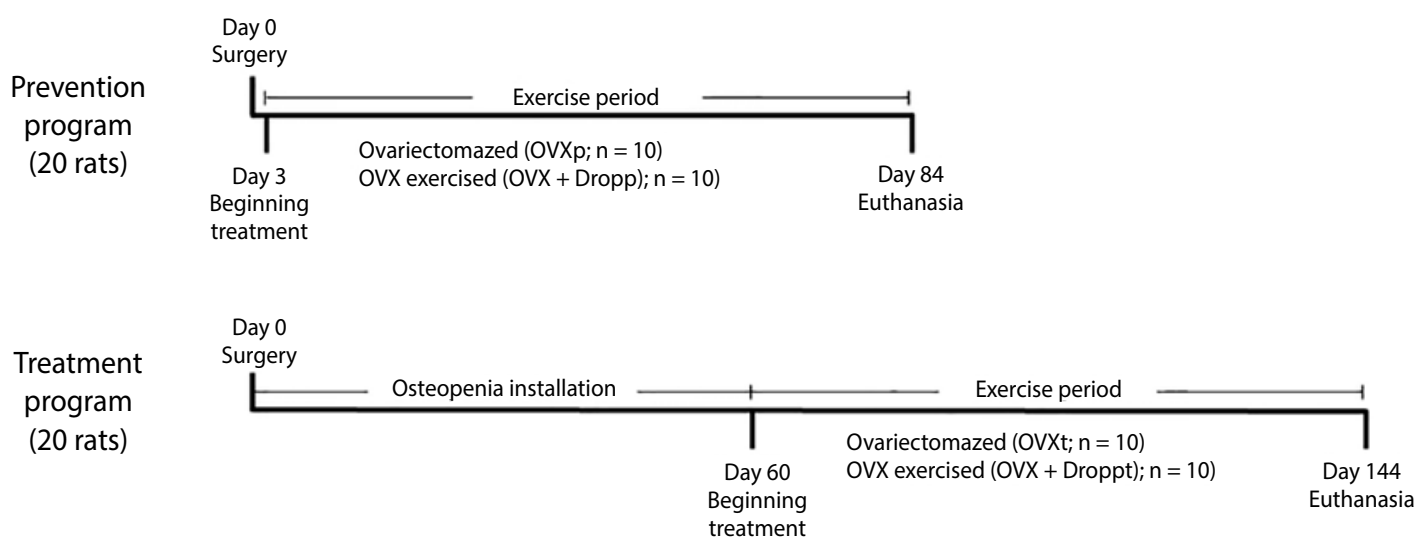

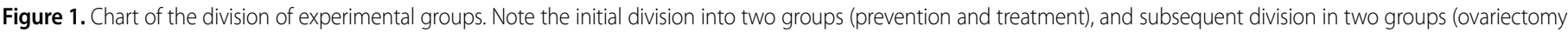
and ovariectomy trained). 
Twenty rats were randomly allocated to the treatment program, and then randomly allocated into one the following two groups: Ovariectomized (OVX) sedentary $\left(\mathrm{OVX}_{\mathrm{t}} ; n=10\right)$, and OVX exercised (OVX+Drop ; $\left.n=10\right)$ (Figure 1).

All animals were weighed weekly. At the end of the experiments, the animals were euthanized with an intraperitoneal overdose of sodium pentobarbital. After confirmation of death, the left tibia was dissected from each rat and stored at $-20^{\circ} \mathrm{C}$ until bone mechanical testing.

The left tibia was dissected and weighed, and their length measured. The mechanical properties of the left tibia were assessed in all the samples collected. After thawing, the tibia diaphysis was subjected to a bending test. All tests were performed using a material testing machine (EMIC ${ }^{\circ}, 10,000$ N; EMIC, São José dos Pinhais, PR, Brazil) with ad hoc accessories. Ultimate load and stiffness were determined from the load/deformation curves.

\section{Statistical analysis}

Data are presented as means \pm SD. A t-student test was used to examine differences between the groups with the use of SigmaStat 3.5 for Windows. Significance level was set at $P<0.05$.

\section{RESULTS}

No rats died during the experiments.

\section{Experiment 1 - Prevention program}

- Preventive effects of physical exercise on bone loss

- High impact exercise preserved stiffness and ultimate load of the tibia skeletal sites tested ( $p<0.05$, Table 1, Figure 2) compared to OVX $X_{p}$.

\section{Experiment 2 - Treatment program}

- Effects of physical exercise on osteopenic bone

- Drop training significantly increased ultimate load and stiffness of the tibia compared to the ovariectomized group ( $p<0.05$, Table 1, Figure 2).

Table 1. Mechanical tests analysis of prevention and treatment groups.

\begin{tabular}{c|c|c|c|c}
\hline & \multicolumn{4}{|c}{ Groups } \\
\hline & OVXp & OVX+Dropp & OVXt & OVX+Dropt \\
\hline Mechanical tests & & & & \\
\hline Ultimate load (N) & & & & \\
\hline Left tibia & $77.80 \pm 15.25$ & $92.69 \pm 12.75^{*}$ & $67.32 \pm 5.74$ & $98.55 \pm 6.57 \#$ \\
\hline Stiffness (N/mm) & & & & \\
\hline Left tibia & $112.15 \pm 19.79$ & $153.18 \pm 28.33^{*}$ & $111.26 \pm 15.16^{*}$ & $163.99 \pm 24.20 \#$ \\
\hline
\end{tabular}

OVXp: Ovariectomized sedentary prevention $(n=10)$, OVX+Dropp: OVX exercised prevention $(n=10)$, OVXt Ovariectomized sedentary treatment $(n=10), O V X+$ Dropt: OVX exercised treatment $(n=10)$. All values are mean $\pm S D$. *indicates statistical difference with $\operatorname{OVXp}$ group $(p<0.05)$. \#indicates statistical difference with $\mathrm{VXX}$ group $(p<0.05)$

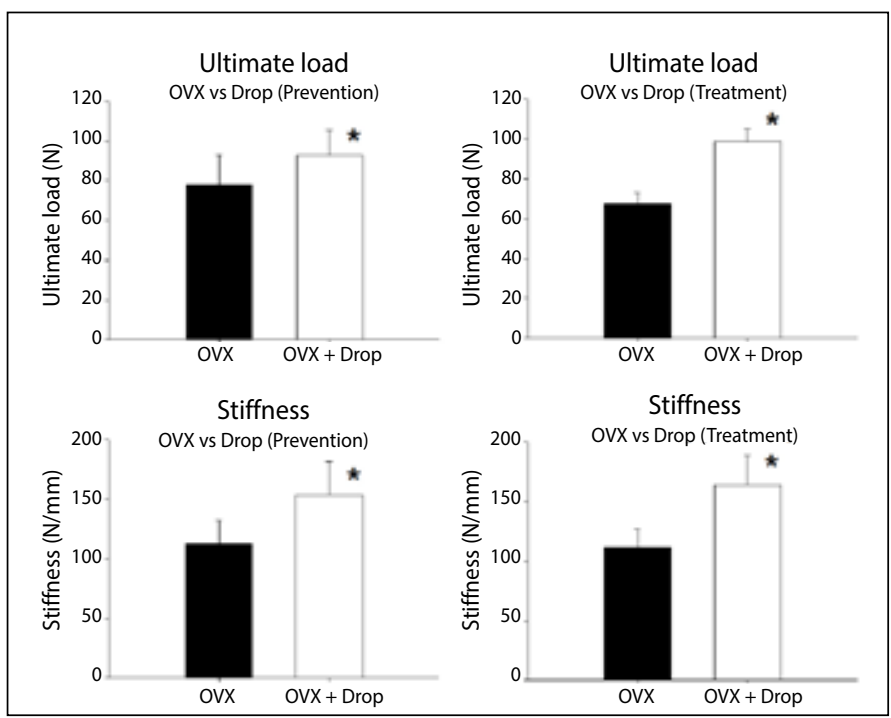

Figure 2. Graph of mean and PD of ultimate load and stiffness comparisons between OVX and OVX+Drop of the experimental groups (ovariectomy and ovariectomy trained).

\section{DISCUSSION}

Exercises can maintain and increase $\mathrm{BMD}^{14-18}$, bone material properties $^{19-21}$, and bone formation, and reduce bone resorption ${ }^{22-25}$. Our investigation confirmed the osteogenic effects of high impact training, and its beneficial effect on bones in ovariectomized estrogen-deficient rats. The increase in ultimate breaking force in the two drop training groups was achieved via improvement in the material properties of the bones tested. These data indicated that drop training stimulated bone formation and increased bone mass and material properties in the OVX rats.

The OVX rat is an established model of estrogen deficiency-induced bone loss, and has been validated for the bone loss seen in human menopause. Several animal studies have used OVX rat models at relatively old ages (36-64 weeks old) to examine the effects of mechanical loading on the skeletal system ${ }^{26}$. Thus, the 20 to 32 week old rats used in that study would be hormonally active and relevant for modeling estrogen deficiency by ovariectomy. Ovariectomy leads to sex hormone deficiency and decreases in bone thickness, bone density, and bone hardness ${ }^{27}$.

We choose 20 drops because in Umemura et al. ${ }^{20}$ results with jumps, this number produced well defined increases in bone material properties. Honda et al. ${ }^{19}$ also imposed a large mechanical stress via jump training. These authors explained that jump training caused great mechanical stresses because of the high ground reaction force on the lower leg imposed by a $40 \mathrm{~cm}$ jump. After that we achieve to analyze the drop effects in bone.

Impact exercise has beneficial effects on bone ${ }^{28}$. Bone responds to mechanical loading by stimulating bone formation where strain is higher ${ }^{29}$. The skeleton is constantly subjected to mechanical loading because of gravitational force and muscle contraction, which stimulate bone remodeling through mechanotransduction. Osteocytes are able to detect the mechanical signals and modulate bone formation and resorption by signaling osteoblasts and osteoclasts, respectively ${ }^{9}$.

The results of this study showed that dropping 20 times per session on a daily basis increased bone material properties in estrogen-deficient rats and control rats in both prevention and treatment groups. High impact drop exercise might therefore improve bone quality, and provide a useful model to compare exercise prescriptions to help define the most efficient and effective exercise recommendations for bone health of premenopausal and menopausal women. The optimal exercise prescription in humans needs further investigation.

There are some methodological limitations of this study. First, we used different periods for the prevention and treatment programs: because of this, we cannot compare their efficiency. Second, we did not perform another quantitative or qualitative analysis of the nature of the bones (i.e. BMD, histomorphometry, micro CT or scanning electron microscopy). However, within the limitations outlined above, the results obtained are univocal and greatly encouraging.

\section{CONCLUSION}

Daily high impact exercise increases bone material properties. Some effects of training were observed in both the prevention and treatment models, suggesting that this exercise regimen is effective in preventing/ reversing bone loss after ovariectomy in rats in whom osteopenia is already established.

All authors declare no potential conflict of interest related to this article. 
AUTHORS' CONTRIBUTIONS: Each author made significant individual contributions to this manuscript. RO (0000-0003-3450-2183)* writing of the manuscript, statistical analysis, reviewing and carrying out of surgeries. FSA (0000-0003-0356-6723)* and FFAV (0000-0001-9995-0249)* surgeries, care of animals, data analysis, and writing of the manuscript. MJF (0000-0003-2669-1359)* surgeries and revision of manuscript. TTS (0000-0002-9135-7456)* revision of manuscript. ACS (0000-0002-3119-2362)* writing and revision as well as all of the intellectual content of the manuscript. ACS revision and intellectual concept of manuscript and elaboration of the entire research project. ${ }^{*}$ ORCID (Open Researcher and Contributor ID).

\section{REFERENCES}

1. Kanis JA. Assessment of fracture risk and its application to screening for postmenopausal osteoporosis: synopsis of a WHO report. WHO Study Group. Osteoporos Int. 1994;4(6):368-81.

2. Cooper C, Rizzoli R, Reginster JY. The International Osteoporosis Foundation: history, objectives and achievements. Osteoporos Int. 2009;20(Suppl 3):S241-2.

3. Compston J. Pathophysiology of atypical femoral fractures and osteonecrosis of the jaw. Osteoporos Int. 2011;22(12):2951-61

4. Guadalupe-Grau A, Fuentes T, Guerra B, Calbet JA. Exercise and bone mass in adults. Sports Med. 2009;39(6):439-68.

5. Abrahin O, Rodrigues RP, Marçal AC, Alves EA, Figueiredo RC, de Sousa EC. Swimming and cycling do not cause positive effects on bone mineral density: a systematic review. Rev Bras Reumatol Engl Ed. 2016;56(4):345-51.

6. Nikander R, Sievänen H, Heinonen A, Daly RM, Uusi-Rasi K, Kannus P. Targeted exercise against osteoporosis: A systematic review and meta-analysis for optimising bone strength throughout life. BMC Med. 2010;8:47.

7. Ju YI, Sone T, Ohnaru K, Tanaka K, Yamaguchi H, Fukunaga M. Effects of different types of jump impact on trabecular bone mass and microarchitecture in growing rats. PLoS One. 2014;9(9):e107953.

8. Ju YI, Sone T, Ohnaru K, Choi HJ, Fukunaga M. Differential effects of jump versus running exercise on trabecular architecture during remobilization after suspension-induced osteopenia in growing rats. J Appl Physiol (1985). 2012;112(5):766-72.

9. Ju YI, Sone T, Ohnaru K, Choi HJ, Choi KA, Fukunaga M. Jump exercise during hindlimb unloading protect against the deterioration of trabecular bone microarchitecture in growing young rats. Springerplus. 2013;2(1):35.

10. Kato T, Terashima T, Yamashita T, Hatanaka Y, Honda A, Umemura Y. Effect of low-repetition jump training on bone mineral density in young women. J Appl Physiol (1985). 2006;100(3):839-43.

11. Lespessailles E, Gadois C, Lemineur G, Do-Huu JP, Benhamou L. Bone texture analysis on direct digital radiographic images: precision study and relationship with bone mineral density at the os calcis. Calcif Tissue Int. 2007;80(2):97-102.

12. McKay HA, MacLean L, Petit M, MacKelvie-O'Brien K, Janssen P, BeckT, et al. "Bounce at the Bell": a novel program of short bouts of exercise improves proximal femur bone mass in early pubertal children. $\mathrm{Br}$ J Sports Med. 2005;39(8):521-6.

13. Kalu DN. The ovariectomized rat model of postmenopausal bone loss. Bone Miner. 1991;15(3):175-91

14. Falcai MJ, Zamarioli A, Okubo R, de Paula FJ, Volpon JB. The osteogenic effects of swimming, jumping, and vibration on the protection of bone quality from disuse bone loss. Scand J Med Sci Sports. 2015;25(3):390-7.
15. Flieger J, Karachalios T, Khaldi L, Raptou P, Lyritis G. Mechanical stimulation in the form of vibration prevents postmenopausal bone loss in ovariectomized rats. Calcif Tissue Int. 1998;63(6):510-4

16. Joo YI, Sone T, Fukunaga M, Lim SG, Onodera S. Effects of endurance exercise on three-dimensional trabecular bone microarchitecture in young growing rats. Bone. 2003;33(4):485-93.

17. Snow-Harter C, Marcus R. Exercise, bone mineral density, and osteoporosis. Exerc Sport Sci Rev. 1991;19:351-88.

18. Swissa-Sivan A, Azoury R, Statter M, Leichter I, Nyska A, Nyska M, et al. The effect of swimming on bone modeling and composition in young adult rats. Calcif Tissue Int. 1990;47(3):173-7.

19. Honda A, Umemura Y, Nagasawa S. Effect of high-impact and low-repetition training on bones in ovariectomized rats. J Bone Miner Res. 2001;16(9):1688-93.

20. Umemura Y, Ishiko T, Yamauchi T, Kurono M, Mashiko S. Five jumps per day increase bone mass and breaking force in rats. J Bone Miner Res. 1997;12(9):1480-5.

21. Umemura Y, Nagasawa S, Sogo N, Honda A. Effects of jump training on bone are preserved after detraining, regardless of estrogen secretion state in rats. J Appl Physiol (1985). 2008;104(4):1116-20.

22. Huang TH, Lin SC, Chang FL, Hsieh SS, Liu SH, Yang RS. Effects of different exercise modes on mineralization, structure, and biomechanical properties of growing bone. J Appl Physiol (1985). 2003;95(1):300-7.

23. Iwamoto J, Shimamura C, Takeda T, Abe H, Ichimura S, Sato Y, et al. Effects of treadmill exercise on bone mass, bone metabolism, and calciotropic hormones in young growing rats. J Bone Miner Metab. 2004;22(1):26-31.

24. Xie L, Jacobson JM, Choi ES, Busa B, Donahue LR, Miller LM, et al. Low-level mechanical vibrations can influence bone resorption and bone formation in the growing skeleton. Bone. 2006;39(5):1059-66.

25. Yang P, Jia B, Ding C, Wang Z, Qian A, Shang P. Whole-body vibration effects on bone before and after hind-limb unloading in rats. Aviat Space Environ Med. 2009;80(2):88-93.

26. Barengolts El, Curry DJ, Bapna MS, Kukreja SC. Effects of endurance exercise on bone mass and mechanical properties in intact and ovariectomized rats. J Bone Miner Res. 1993;8(8):937-42.

27. Aswar UM, Mohan V, Bodhankar SL. Antiosteoporotic activity of phytoestrogen-rich fraction separated from ethanol extract of aerial parts of Cissus quadrangularis in ovariectomized rats. Indian J Pharmacol. 2012;44(3):345-50.

28. Honda A, Sogo N, Nagasawa S, Kato T, Umemura Y. Bones benefits gained by jump training are preserved after detraining in young and adult rats. J Appl Physiol (1985). 2008;105(3):849-53.

29. Turner CH. Bone strength: current concepts. Ann NY Acad Sci. 2006;1068:429-46. 